\title{
STRATEGI IMPLEMENTASI KURIKULUM INTI PROGRAM DIPLOMA III REKAM MEDIS DAN INFORMASI KESEHATAN
}

\author{
(Studi Kasus pada Program Diploma III Rekam Medis Sekolah Vokasi \\ Universitas Gadjah Mada) \\ Nuryati $^{1}$, Nur Rokhman ${ }^{2}$ \\ Program Diploma, Rekam Medis, Sekolah Vokasi UGM ${ }^{1,2}$ \\ nur3yati@yahoo.com1, nurrokhman@ymail.com ${ }^{2}$
}

\begin{abstract}
ABSTRAK
Berdasarkan UU No 12 tahun 2012 tentang Pendidikan Tinggi dinyatakan bahwa Kurikulum pendidikan tinggi merupakan seperangkat rencana dan pengaturan mengenai tujuan, isi, dan bahan ajar serta cara yang digunakan sebagai pedoman penyelenggaraan kegiatan pembelajaran untuk mencapai tujuan Pendidikan Tinggi. Sedangkan berdasarkan Kepmendiknas No. 045 tahun 2002 tentang Kurikulum Inti Perguruan Tinggi menyatakan bahwa kurikulum inti merupakan penciri dari kompetensi utama serta sebagai dasar untuk mencapai kompetensi lulusan. Tujuan dari penelitian ini adalah bagaimana implementasi kurikulum inti di Program Diploma III Rekam Medis Sekolah Vokasi serta faktor yang mendukung dan menghambat dalam implementasi dan bagaimana strategi yang dilakukan.

Penelitian ini termasuk penelitian lapangan (penelitian deskriptif kualitatif) dengan metode pengumpulan data melalui wawancara, observasi, studi dokumentasi dan studi kepustakaan. Sedangkan analisis datanya dengan pendekatan induktif.

Program Diploma III Rekam Medis Sekolah Vokasi UGM telah mengimplementasikan kurikulum berdasarkan kurikulum inti yang dikeluarkan oleh Kepala Badan Pengembangan dan Pemberdayaan Sumber Daya Manusia Kesehatan Nomor: HK.02.05/ I/ III/ 2/ 08661/ 2011 Tentang Kurikulum Inti Program Pendidikan Diploma III Rekam Medis dan Informasi Kesehatan sejak Tahun Ajaran 2012/2013 atau Agustus 2012. Langkah-langkah implementasi dimulai dari pemetaan kurikulum, pembenahan secara internal dan sosialisasi kepada seluruh dosen serta organisasi profesi dan stakeholder. Permasalahan terjadi terkait peralihan kurikulum serta sudah ada strategi yang diupayakan untuk mengatasi permasalahan yang ada.
\end{abstract}

Key word: implementasi, kurikulum, rekam medis

\section{PENDAHULUAN}

Pendidikan merupakan rangkaian proses belajar mengajar yang mempunyai tujuan memperoleh pengetahuan, pandangan, dan ketrampilan yang diperlukan untuk menghasilkan suatu sikap dan perilaku tertentu ketika menghadapi suatu keadaan tertentu (Machfoedz, et.al., 2005) Pembelajaran dapat dipandang sebagai suatu sistem untuk mencapai kompetensi, pengetahuan, ketrampilan dan sikap dari peserta didik (Pribadi, 2009). Sedangkan berdasarkan Peraturan Pemerintah No.17 Tahun 2010 tentang Pengelolaan dan Penyelenggaraan Pendidikan dinyatakan bahwa pembelajaran adalah proses interaksi peserta didikdengan pendidik dan/ atau sumber belajar padasuatu lingkungan belajar
Berdasarkan UU No 12 tahun 2012 tentang Pendidikan Tinggi dinyatakan bahwa pembelajaran adalah proses interaksi mahasiswa dengan dosen dan sumber belajar pada suatu lingkungan belajar. Serta mempunyai tujuan mengembangkan potensi Mahasiswa agar menjadi manusia yang beriman dan bertakwa kepada Tuhan Yang Maha Esa dan berakhlak mulia, sehat, berilmu, cakap, kreatif, mandiri, terampil, kompeten, dan berbudaya untuk kepentingan bangsa. Salah satu program dalam pendidikan tinggi adalah program diploma.

Program diploma adalah program yang menyiapkan Mahasiswa menjadi praktisi yang terampil untuk memasuki dunia kerja sesuai dengan bidang keahliannya. Program Diploma III Rekam Medis 
Nuryati, dkk. Strategi Implementasi Kurikulum Inti Program

dan Informasi Kesehatan merupakan program yang menyiapkan mahasiswa terampil pada pengelolaan manajemen informasi kesehatan. Program Diploma III Rekam Medis dan Informasi Kesehatan mengacu pada standar kompetensi yang tertuang dalam standar profesi pada Kepmenkes No.377 Tahun 2007 dalam penerapan kurikulumnya. Berdasarkan UU No 12 tahun 2012 tentang Pendidikan Tinggi dinyatakan bahwa Kurikulum pendidikan tinggi merupakan seperangkat rencana dan pengaturan mengenai tujuan, isi, dan bahan ajar serta cara yang digunakan sebagai pedoman penyelenggaraan kegiatan pembelajaran untuk mencapai tujuan Pendidikan Tinggi. Kurikulum dikembangkan oleh setiap PerguruanTinggi dengan mengacu pada Standar Nasional Pendidikan Tinggi untuk setiap Program Studi yang mencakup pengembangan kecerdasan intelektual, akhlak mulia, dan keterampilan. Berdasarkan Kepmendiknas No. 232 tahun 2000 tentang Pedoman Penyusunan Kurikulum Pendidikan Tinggi dan Penilaian Hasil Belajar Mahasiswa dinyatakan bahwa kurikulum pendidikan tinggi adalah seperangkat rencana dan pengaturan mengenai isi maupun bahan kajian dan pelajaran serta cara penyampaian dan penilainnya yang digunakan sebagai pedoman penyelenggaraan kegiatan belajar-mengajar di perguruan tinggi. Sedangkan berdasarkan Kepmendiknas No. 045 tahun 2002 tentang Kurikulum Inti Perguruan Tinggi menyatakan bahwa kurikulum inti merupakan penciri dari kompetensi utama serta sebagai dasar untuk mencapai kompetensi lulusan.

Berdasarkan Kepmenkes No 377 Tahun 2007 tersebut Asosiasi Profesi Perekam Medis dan Informasi Kesehatan Indonesia (PORMIKI) bekerjasama dengan Badan Pengembangan dan Pemberdayaan Sumber Daya Manusia Kesehatan telah membuat kurikulum inti Program Pendidikan Diploma III Rekam Medis dan Informasi Kesehatan. Keputusan tersebut tertuang dalam Keputusan Kepala Badan Pengembangan dan Pemberdayaan Sumber Daya Manusia Kesehatan Nomor: HK.02.05/ I/ III/ 2/ 08661/ 2011 Tentang Kurikulum Inti Program Pendidikan Diploma III Rekam Medis dan Informasi Kesehatan. Kurikulum inti tersebut merupakan pedoman umum yang mendasari institusi penyelenggara Program Pendidikan Diploma III Rekam Medis dan Informasi Kesehatan di seluruh Indonesia dalam mengembangkan kurikulum. Berdasarkan Keputusan tersebut, institusi penyelenggara pendidikan wajib melaksanakan
Kurikulum Inti ini selambat-lambatnya dua tahun sejak keputusan tersebut ditetapkan.

Program Diploma III Rekam Medis Sekolah Vokasi sejak didirikan tahun 2000 telah melakukan revisi kurikulum pada tahun 2006 dan 2012. Pada revisi tahun 2012 telah mengacu pada kurikulum inti yang telah dikeluarkan oleh Badan pengembangan dan Pemberdayaan Sumber Daya Manusia Kesehatan.

Oleh karena itu penelitian ini akan menitik beratkan pada permasalahan-permasalahan dan strategi yang dilakukan oleh Program Diploma III Rekam Medis Sekolah Vokasi UGM dalam penerapan Kurikulum Inti Program Pendidikan Diploma III Rekam Medis dan Informasi Kesehatan. Dimana kurikulum tersebut menggunakan pendekatan kurikulum berbasis kompetensi (KBK) sesuai dengan Surat Keputusan Mendiknas No. 19 tahun 2005 tentang Standar Nasional Pendidikan.

\section{METODE}

Dalam penelitian ini yang menjadi subyek penelitian adalah dosen dan mahasiswa Program Diploma III Rekam Medis Sekolah Vokasi UGM. Berdasarkan obyek penelitian, baik tempat maupun sumber data, maka penelitian ini termasuk penelitian lapangan (field research) yang termasuk penelitian kualitatif deskriptif. Dalam pengumpulan data, peneliti menggunakan metode kajian kepustakaan, wawancara, observasi, dan dokumentasi. Sedangkan analisisnya adalah deskriptif-kualitatif dengan pendekatan induktif.

Teknik pengumpulan data dan instrumen yang digunakan pada penelitian ini adalah observasi (ceklisobservasi), wawancara (panduan wawancara), dan studi dokumentasi (ceklis studi dokumentasi) . Alat yang digunakan adalah ceklis studi dokumentasi.

\section{HASIL DAN PEMBAHASAN}

\section{Tahapan Implementasi Kurikulum Inti Pada Program Diploma III Rekam Medis Sekolah Vokasi UGM}

Program Diploma III Rekam Medis Sekolah Vokasi memulai penerimaan mahasiswa baru sejak tahun 2000 dengan menggunakan kurikulum dari Pusat Pendidikan dan Pelatihan Tenaga Kesehatan Departemen Kesehatan Tahun 1994. Total beban sistem kredit semester (SKS)nya adalah 120 sks. 
Pada tahun 2006 dilakukan revisi kurikulum pada tingkat Program Sarjana (S1) dilingkungan UGM yang berdampak pada Program Diploma III Rekam Medis melakukan revisi yang bersifat mayor. Revisi kurikulum yang dilakukan pada tahun 2006 adalah menghilangkan matakuliah magang, penyajian data statistik, mengurangi jumlah sks pada matakuliah metodologi riset, tata arsip dinamis, problem oriented medical record, komputerisasi data rekam medis, tata desain formulir, dan praktikum basis data dengan total beban sks menjadi 111 sks.

Berdasarkan Kepmendiknas No. 232 Tahun 2000 tentang Pedoman Penyusunan Kurikulum Pendidikan Tinggi dan Penilaian Hasil Belajar Mahasiswa dinyatakan bahwa beban studi program diploma III sekurang-kurangnya 110 sks dan sebanyak-banyaknya 120 sks. Pelaksanaan revisi kurikulum selanjutnya sudah dimulai sejak tahun 2011, akan tetapi pihak UGM menjadwalkan untuk kegiatan revisi kurikulum program diploma III pada tahn 2012. Pada revisi kurikulum tahun 2012 mengimplementasikan kurikulum inti dari Kementerian Kesehatan. Pada revisi tersebut terjadi perubahan paradigma pembelajaran, yang semula berdasarkan logika keilmuan menjadi berdasar strategi pembelajaran (sistem blok).

Berikut adalah tahapan-tahapan implementasi kurikulum inti pada Program Diploma III Rekam Medis Sekolah Vokasi UGM:

\section{Pemetaan kondisi eksisting dari kurikulum 2006}

Pada kegiatan ini dilakukan pemetaan kurikulum 2006 dengan menetapkan prosentase pencapaian dengan membandingkan draf kurikulum inti dari Kemenkes RI. Kegiatan ini dihadiri oleh dosen Program Diploma III Rekam Medis Sekolah Vokasi, Ketua DPD Pormiki DIY dan Ketua Bagian Penelitian dan Pengembangan (Litbang) DPP Pormiki. Kegiatan tersebut dilaksanakan pada tanggal 5 Juli 2011 dan mengahasilkan prosentase pencapaian berkisar dari $60-100 \%$ berdasarkan kurikulum inti.

Berikut kutipan tabel pemetaan kurikulum 2006 terhadap kurikulum inti pada Program Diploma III Rekam Medis Sekolah Vokasi UGM:

Tabel 1. Kutipan Kondisi Eksisting Kurikulum Program Diploma III Rekam Medis Sekolah Vokasi UGM

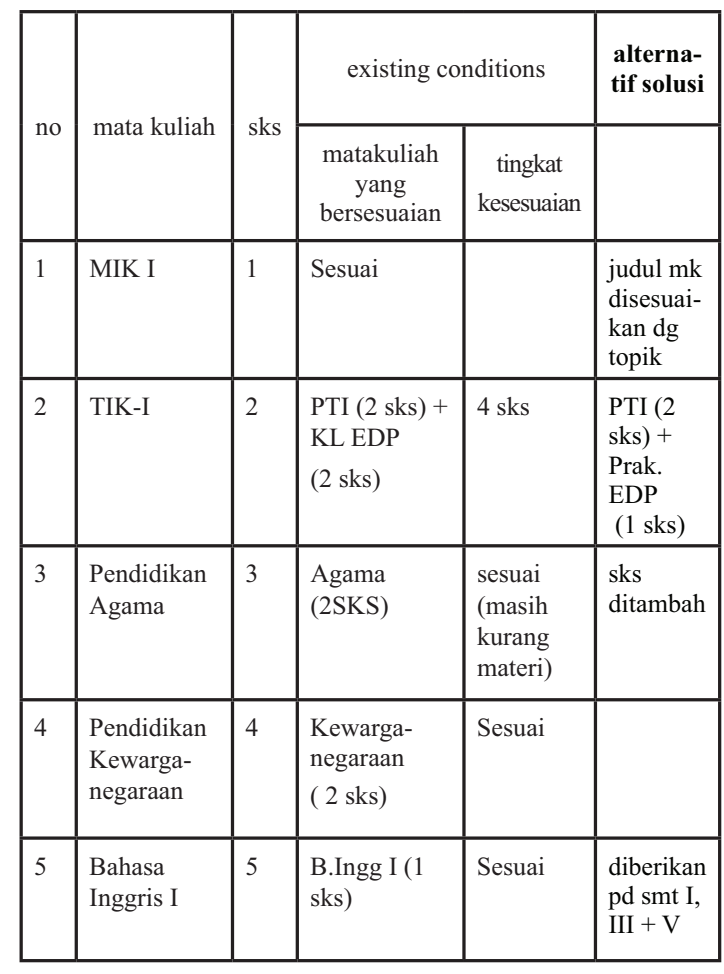

\section{Pembenahan kurikulum secara internal}

Berdasarkan hasil pemetaan, pihak internal Program Diploma III Rekam Medis Sekolah Vokasi UGM melakukan pembenahan kurikulum dengan mengacu pada draf kurikulum inti. Akan tetapi draf kurikulum revisi tahun 2011 belum mendapatkan pengesahan dari Senat

\begin{tabular}{|c|c|c|}
\hline $\begin{array}{c}\text { MATAKULIAH } \\
\text { D3 REKAM } \\
\text { MEDIS UGM } \\
2006\end{array}$ & $\begin{array}{c}\text { MATAKULIAH } \\
\text { INTI } \\
\text { PUSDIKNAKES } \\
2011\end{array}$ & $\begin{array}{c}\text { MATAKULIAH } \\
\text { D3 REKAM } \\
\text { MEDIS REVISI } \\
2012\end{array}$ \\
\hline $\begin{array}{l}\text { PSRM I } \\
\text { (1 sks) } \\
\text { Praktek PSRM I } \\
(1 \text { sks) }\end{array}$ & MIK I (2 sks) & $\begin{array}{l}\text { MIK I (konsep } \\
\text { MIK) } \\
\text { (2 sks) }\end{array}$ \\
\hline $\begin{array}{l}\text { Administrasi } \\
\text { Kesehatan } \\
(2 \text { sks) } \\
\text { Pengantar } \\
\text { Manajemen } \\
\text { Kesehatan } \\
\text { (2 sks) }\end{array}$ & $\begin{array}{l}\text { MUK I (Organisasi } \\
\& \text { manajemen) (3 } \\
\text { sks) }\end{array}$ & $\begin{array}{l}\text { MUK I (Organisasi } \\
\& \text { manajemen) ( } 3 \\
\text { sks) }\end{array}$ \\
\hline
\end{tabular}

UGM karena terdapat kebijakan internal UGM bahwasanya revisi kurikulum untuk program diploma adalah tahun 2012.

Berikut kutipan tabel pembenahan yang dilakukan pada draf kurikulum 2012: 
Dedy, dkk. The Role og Health Information Management

Tabel 2. Pembenahan Kurikulum 2012

\begin{tabular}{|c|c|c|}
\hline $\begin{array}{c}\text { MATAKULIAH } \\
\text { D3 REKAM } \\
\text { MEDIS UGM } \\
2006 \\
\end{array}$ & $\begin{array}{l}\text { MATAKULIAH } \\
\text { INTI } \\
\text { PUSDIKNAKES } \\
2011 \\
\end{array}$ & $\begin{array}{c}\text { MATAKULIAH } \\
\text { D3 REKAM } \\
\text { MEDIS REVISI } \\
2012 \\
\end{array}$ \\
\hline $\begin{array}{l}\text { Pendidikan Agama } \\
\text { (2 sks) }\end{array}$ & $\begin{array}{l}\text { Pendidikan Agama } \\
(2 \mathrm{sks})\end{array}$ & $\begin{array}{l}\text { Pendidikan Agama } \\
(2 \mathrm{sks})\end{array}$ \\
\hline $\begin{array}{l}\text { Bahasa Indonesia } \\
(2 \mathrm{sks})\end{array}$ & $\begin{array}{l}\text { Bahasa Indonesia } \\
\text { (2 sks) }\end{array}$ & $\begin{array}{l}\text { Bahasa Indonesia } \\
(2 \mathrm{sks})\end{array}$ \\
\hline $\begin{array}{l}\text { Bahasa Inggris I } \\
\text { (1 sks) }\end{array}$ & $\begin{array}{l}\text { Bahasa Inggris } \\
(2 \mathrm{sks})\end{array}$ & $\begin{array}{l}\text { Bahasa Inggris I } \\
\text { (2 sks) }\end{array}$ \\
\hline \multirow[t]{2}{*}{$\begin{array}{l}\text { Biomedik fisiologi } \\
(2 \mathrm{sks}) \\
\text { Biomedik Anatomi } \\
\text { I ( } 2 \mathrm{sks}) \\
\text { IPLK I (1 sks) } \\
\text { Praktek IPLK } 1 \\
(1 \mathrm{sks})\end{array}$} & \multirow[t]{2}{*}{$\begin{array}{l}\text { Klasifikasi \& } \\
\text { K o d e fikas i } \\
\text { Penyakit dan } \\
\text { Masalah Terkait I } \\
\text { (KKPMT I) } \\
\text { (6 sks) }\end{array}$} & $\begin{array}{l}\text { KKPMT I A } \\
(2 \mathrm{sks}) \\
\text { (Biomedik } \\
\text { Anatomi, } \\
\text { Biomedik } \\
\text { Fisiologi, } \\
\text { Biomedik } \\
\text { Patologi sistem } \\
\text { kardiovaskuler, } \\
\text { respirasi, dan } \\
\text { muskuloskeltal) }\end{array}$ \\
\hline & & $\begin{array}{l}\text { KKPMT I B } \\
\text { (2 sks) } \\
\text { (Terminologi } \\
\text { Medis dan } \\
\text { Kodefikasi } \\
\text { \& Klasifikasi } \\
\text { Penyakit } \\
\text { \& Masalah } \\
\text { Terkait sistem } \\
\text { kardiovaskuler, } \\
\text { respirasi, dan } \\
\text { muskuloskeltal) }\end{array}$ \\
\hline
\end{tabular}

\section{Sosialisasi kurikulum kepada seluruh dosen}

Pada tanggal 19 - 20 Juni 2012 dilakukan kegiatan workshop dan sosialisasi kurikulum 2012 Program Diploma III Rekam Medis Sekolah Vokasi UGM kepada seluruh dosen. Pada kegiatan tersebut selain sosialisasi, dilakukan juga penentuan materi atas matakuliah pada kurikulum baru dengan cara pengelompokkan dosen berdasarkan keilmuan. Berikut kutipan hasil dari penentuan materi kuliah berdasarkan matakuliah pada kurikulum 2012.

Tabel 3. Penentuan Materi Berdasarkan Matakuliah Kurikulum 2012

\begin{tabular}{|l|l|c|}
\hline \multirow{2}{*}{$\begin{array}{c}\text { Mata- } \\
\text { kuliah }\end{array}$} & \multicolumn{1}{|c|}{ Materi } & Sks \\
\hline \multirow{3}{*}{$\begin{array}{l}\text { MUK I } \\
\text { (Organisasi } \\
\&\end{array}$} \\
\cline { 2 - 3 } $\begin{array}{l}\text { manajemen }) \\
(3 \text { sks })\end{array}$ & Teori Dasar Organisasi dan Manajemen & 2 \\
\cline { 2 - 3 } & Perencanaan & 1 \\
\cline { 2 - 3 } & Pengorganisasian & 1 \\
\cline { 2 - 3 } & Monitoring dan Evaluasi & 2 \\
\cline { 2 - 3 } & Gaya Kepemimpinan & 1 \\
\hline
\end{tabular}

\begin{tabular}{|c|c|c|}
\hline & Motivasi \& Komunikasi & 2 \\
\hline & Administrasi Kesehatan & 4 \\
\hline \multirow{5}{*}{$\begin{array}{l}\text { MUK III } \\
\text { (Dasar- } \\
\text { dasar } \\
\text { Akuntansi) } \\
\text { (3 sks) }\end{array}$} & Pengertian Akuntansi Umum & 1 \\
\hline & Pengertian transaksi dan penjurnalan & 1 \\
\hline & Penyusunan Neraca saldo & 1 \\
\hline & Penyusunban Renaca lajur & 1 \\
\hline & Penyusunan Laporan Keuangan & 1 \\
\hline \multirow{9}{*}{$\begin{array}{l}\text { MUK III } \\
\text { (Dasar- } \\
\text { dasar } \\
\text { Akuntansi) } \\
\text { (3 sks) }\end{array}$} & Latihan / Praktek & 1 \\
\hline & Pengertian Akuntansi Biaya (Umum) & 1 \\
\hline & Pengertian Biaya dan Hasil & 1 \\
\hline & Perhitungan Biaya di Rumah Sakit & 1 \\
\hline & Perhitungan Unit Cost RS (URMIK) & 1 \\
\hline & Latihan / Praktek & 1 \\
\hline & Pengertian Anggaran (Umum) & 1 \\
\hline & Penyusunan Anggaran RS & 1 \\
\hline & Latihan / Praktek & 1 \\
\hline
\end{tabular}

\section{Sosialisasi kurikulum}

Sosisalisasi kurikulum dilakukan pada beberapa kegiatan, diantaranya pada kegiatan Kongres PORMIKI di Pontianak, Rapat Tahunan Anggota Aptirmik di Yogyakarta, serta pada Kemitraan Dinas Kesehatan Provinsi dengan Perguruan Tinggi Rekam Medis dan Informasi Kesehatan DIY di Yogyakarta. Pada kegiatan tersebut diperoleh masukan untuk perbaikan dari kurikulum Program Diploma III Rekam Medis Sekolah Vokasi UGM. Diantara perbaikan adalah pemetaan nama matakuliah terhadap nama matakuliah berdasarkan kurikulum inti.

\section{Penetapan kurikulum oleh senat}

Pada awal semester 2012/2013 kurikulum Program Diploma III Rekam Medis Sekolah Vokasi UGM diresmikan oleh Senat Sementara Sekolah Vokasi dan mulai diberlakukan bagi mahasiswa baru angkatan 2012/2013 serta diberlakukannya kurikulum perubahan bagi mahasiswa angkatan 2011/2012 dan sebelumnya. Sebelum diresmikan oleh senat, kurikulum tersebut dipresentasikan dalam pleno yang diadakan oleh Sekolah Vokasi. Berdasarkan hasil pleno tersebut, terdapat pengurangan jumlah sks yang sebelumnya tedapat 115 sks menjadi 111 sks. Yaitu pada matakuliah praktek kerja lapangan (PKL) yang semula berjumlah 2 sks (selama 2 minggu di lapangan) 
menjadi 1 sks. Hal ini dikarenakan aturan inernal Sekolah Vokasi untuk matakuliah praktek kerja lapangan yang berbobot 2 sks harus dilakukan selama 3 bulan di lapangan. Jumlah matakuliah PKL semula 8 sks yang terdiri dari PKL I, II, III, dan IV menjadi 4 sks. Untuk menambah kesempatan mahasiswa mendapatkan pengalaman di tempat pelayanan kesehatan, maka pada matakuliah Tugas Akhir selain menyusun laporan, mahasiswa diwajibkan melaksanakan pengabdian selama 4 minggu $x 8$ jam di instansi pelayanan kesehatan.

Faktor Yang Mendukung dan Menghambat Serta Strategi Yang Diterapkan Pada Implementasi Kurikulum Inti

Berdasarkan hasil pengamatan diperoleh data faktor yang mendukung dalam implementasi kurikulum inti adalah sebagai berikut:

Kebijakan Internal UGM yang mengharuskan dilakukannya revisi kurikulum program diploma III pada tahun 2012

Adanya kurikulum inti yang dikeluarkan oleh Kepala Badan Pengembangan dan Pemberdayaan Sumber Daya Manusia Kesehatan Nomor: HK.02.05/ I/ III/ 2/ 08661/ 2011 Tentang Kurikulum Inti Program Pendidikan Diploma III Rekam Medis dan Informasi Kesehatan

Berdasarkan hasil workshop dan sosialisasi kepada sivitas akademik (dosen dan mahasiswa) mereka setuju dilakukan revisi kurikulum, karena dengan kurikulum yang baru matakuliah lebih terintegrasi. Bagi dosen yang mendapatkan matakuliah baru atau terintegrasi dengan matakuliah lain di kurikulum baru tidak merasa keberatan, dikarenakan pada kurikulum baru lebih jelas kompetensi yang harus dicapai oleh mahasiswa.

Dukungan dan kerjasama yang baik dari asosiasi perguruan tinggi rekam medis (Aptirmik) dan organisasi profesi rekam medis (Pormiki)

Pada implementasi kurikulum baru pada mahasiswa angkatan 2012 dan kurikulum peralihan bagi mahasiswa angkatan 2011 dan sebelumnya, Program Diploma III Rekam Medis Sekolah Vokasi UGM melakukan pemetaan kesetaraan matakuliah. Hal ini dilakukan agar pada implementasi kurikulum mahasiwa tidak dirugikan. Kesetaraan tersebut adalah:

\section{Kesetaraan penuh}

Sebuah mata kuliah pada kurikulum lama setara dengan sebuah mata kuliah pada kurikulum baru.
Berikut disajikan dalam tabel 4 terkait nama matakuliah yang kesetaraannya secara penuh.

Tabel 4. Daftar Matakuliah Yang Mempunyai Kesetaraan Penuh pada Kurikulum 2012

\begin{tabular}{|c|c|c|}
\hline No & $\begin{array}{c}\text { Matakuliah di } \\
\text { Kurikulum } 2012\end{array}$ & $\begin{array}{c}\text { Matakuliah di } \\
\text { Kurikulum } 2006\end{array}$ \\
\hline 1 & Pendidikan Agama Islam & Pendidikan Agama Islam \\
\hline 2 & Pancasila & Pancasila \\
\hline 3 & Bahasa Indonesia & Bahasa Indonesia \\
\hline 4 & $\begin{array}{l}\text { Pendidikan } \\
\text { Kewarganegaraan }\end{array}$ & $\begin{array}{l}\text { Pendidikan } \\
\text { Kewarganegaraan }\end{array}$ \\
\hline 5 & $\begin{array}{l}\text { Pengantar Teknologi } \\
\text { Informasi }\end{array}$ & $\begin{array}{l}\text { Pengantar Teknologi } \\
\text { Informasi }\end{array}$ \\
\hline 6 & Biostatistika & Biostatistika \\
\hline 7 & Farmakologi & Biomedik Farmakologi \\
\hline 8 & Quality Assurance & Quality Assurance \\
\hline 9 & $\begin{array}{l}\text { Algoritma dan Struktur } \\
\text { Data I }\end{array}$ & $\begin{array}{l}\text { Pemograman } \\
\text { Tersetruktur }\end{array}$ \\
\hline 10 & Basis Data I & Basis Data \\
\hline 11 & Epidemiologi & Epidemiologi \\
\hline 12 & $\begin{array}{l}\text { Perencanaan Anggaran } \\
\text { pada Sarana Pelayanan } \\
\text { Kesehatan }\end{array}$ & Dasar-dasar Akuntansi \\
\hline 13 & $\begin{array}{l}\text { Akreditasi dan } \\
\text { Manajemen Resiko }\end{array}$ & Evaluasi Pelayanan \\
\hline 14 & $\begin{array}{l}\text { Statistik Sarana } \\
\text { Pelayanan Kesehatan }\end{array}$ & $\begin{array}{l}\text { Statistik Sarana } \\
\text { Pelayanan Kesehatan }\end{array}$ \\
\hline 15 & $\begin{array}{l}\text { Pengantar Jaringan } \\
\text { Komputer }\end{array}$ & Jaringan Komputer \\
\hline 16 & $\begin{array}{l}\text { Metodologi Penelitian } \\
\text { Kesehatan }\end{array}$ & Metodologi Riset \\
\hline 17 & Kapita Selekta & Kapita Selekta \\
\hline
\end{tabular}

\section{Kesetaraan Sebagian}

Sebuah mata kuliah pada kurikulum lama setara dengan sebuah mata kuliah pada kurikulum baru. Berikut disajikan tabel 5 mata kuliah yang mempunyai kesetaraan sebagian, sehingga mahasiswa dapat mengulang matakuliah dengan memperhatikan kesetaraan ini. Misalkan, mahasiswa akan mengulang matakuliah ergonomi, maka perkuliahan tersebut dititipkan pada matakuliah MUK II. 
Dedy, dkk. The Role og Health Information Management

Tabel 5. Daftar Matakuliah Yang Mempunyai Kesetaraan Sebagian pada Kurikulum 2012

\begin{tabular}{|c|c|c|}
\hline No & $\begin{array}{c}\text { Matakuliah di } \\
\text { Kurikulum } 2012\end{array}$ & $\begin{array}{c}\text { Matakuliah di Kurikulum } \\
2006\end{array}$ \\
\hline 1 & Bahasa Inggris I & $\begin{array}{l}\text { Bahasa Inggris I } \\
\text { Bahasa Inggris II }\end{array}$ \\
\hline 2 & $\begin{array}{l}\text { MIK I (Konsep Dasar } \\
\text { Pengelolaan RMIK) }\end{array}$ & $\begin{array}{l}\text { Pengelolaan Sistem Rekam } \\
\text { Medis (PSRM) I } \\
\text { Praktek PSRM I }\end{array}$ \\
\hline 3 & Bahasa Inggris II & $\begin{array}{l}\text { Bahasa Inggris Kesehatan I } \\
\text { Bahasa Inggris Kesehatan II }\end{array}$ \\
\hline 4 & $\begin{array}{l}\text { MIK II (Sistem Informasi } \\
\text { RMIK) } \\
\text { Praktek MIK II }\end{array}$ & $\begin{array}{l}\text { Pengelolaan Sistem Rekam } \\
\text { Medis (PSRM) II } \\
\text { Praktek PSRM II }\end{array}$ \\
\hline 5 & $\begin{array}{l}\text { MIK III (Desain } \\
\text { Formulir) } \\
\text { Praktek MIK III }\end{array}$ & $\begin{array}{l}\text { Pengelolaan Sistem Rekam } \\
\text { Medis (PSRM) III } \\
\text { Praktek PSRM III }\end{array}$ \\
\hline 6 & $\begin{array}{l}\text { MUK I (Organisasi \& } \\
\text { Manajemen) }\end{array}$ & $\begin{array}{l}\text { Administrasi Kesehatan } \\
\text { Masyarakat } \\
\text { Pengantar Manajemen } \\
\text { Kesehatan }\end{array}$ \\
\hline 7 & $\begin{array}{l}\text { TIK } 6 \text { (Proyek Sistem } \\
\text { Informasi Manajemen } \\
\text { pada Sarana Pelayanan } \\
\text { Kesehatan) }\end{array}$ & $\begin{array}{l}\text { Sistem Informasi } \\
\text { Manajemen } \\
\text { Komputerisasi Data Rekam } \\
\text { Medis }\end{array}$ \\
\hline 8 & $\begin{array}{l}\text { MIK IV (Etika \& Hukum } \\
\text { Kesehatan) }\end{array}$ & $\begin{array}{l}\text { Etika Profesi } \\
\text { Hukum Kesehatan }\end{array}$ \\
\hline 9 & $\begin{array}{l}\text { M I K V ( S i s t e m } \\
\text { Pembiayaan pada Sarana } \\
\text { Pelayanan Kesehatan } \\
\text { Praktek MIK V }\end{array}$ & $\begin{array}{l}\text { Pengelolaan Sistem Rekam } \\
\text { Medis (PSRM) IV } \\
\text { Praktek PSRM IV }\end{array}$ \\
\hline 10 & $\begin{array}{l}\text { MUK II (Perencanaan } \\
\text { SDM \& Fasilitas Unit } \\
\text { Kerja RMIK) } \\
\text { Praktek MUK II }\end{array}$ & $\begin{array}{l}\text { Pengelolaan Sistem Rekam } \\
\text { Medis (PSRM) V } \\
\text { Praktek PSRM V }\end{array}$ \\
\hline
\end{tabular}

\section{Tidak Ada Kesetaraan}

Sebuah mata kuliah pada kurikulum baru tidak memiliki kesetaraan dengan mata kuliah pada kurikulum lama, begitu pula sebaliknya. Sehingga mahasiswa tidak wajib untuk menempuh mata kuliah tersebut, dengan kata lain mata kuliah tersebut menjadi mata kuliah pilihan bagi mahasiswa dengan kurikulum peralihan. Berikut disajikan pada tabel 6 terkait mata kuliah yang tidak mempunyai kesetaraan.

Tabel 6. Daftar Matakuliah yang Tidak Mempunyai Kesetaraan pada Kurikulum 2012

\begin{tabular}{|c|c|c|}
\hline No & $\begin{array}{c}\text { Matakuliah di } \\
\text { Kurikulum 2012 }\end{array}$ & $\begin{array}{c}\text { Matakuliah di } \\
\text { Kurikulum 2006 }\end{array}$ \\
\hline 1 & Ilmu Sosial dan Budaya Dasar & --- (baru) \\
\hline
\end{tabular}

\begin{tabular}{|c|l|l|}
\hline 2 & Praktek SIK I & -- (baru) \\
\hline 3 & $\begin{array}{l}\text { MMIK III } \\
\text { Praktek MMIK III }\end{array}$ & --- (baru) \\
\hline 4 & Praktek SIK II & --- (baru) \\
\hline 5 & Kewirausahaan & --- (baru) \\
\hline 6 & Praktek MUK II & --- (baru) \\
\hline 7 & $\begin{array}{l}\text { Praktek Metodologi Penelitian } \\
\text { Kesehatan }\end{array}$ & --- (baru) \\
\hline 8 & Praktek KKPMT V & --- (baru) \\
\hline 9 & Praktek KKPMT VI & --- (baru) \\
\hline 10 & Praktek KKPMT VII & --- (baru) \\
\hline
\end{tabular}

\section{Kesetaraan Blok}

Sekelompok matakuliah pada kurikulum baru setara dengan sekelompok mata kuliah pada kurikulum lama. Sehingga bagi mahassiwa dengan kurikulum peralihan tidak diperbolehkan mengambil sebagian dari matakuliah blok. Berikut disajikan daftar matakuliah yang mempunyai kesetaraan blok.

Tabel 7. Daftar Matakuliah yang Mempunyai Kesetaraan Blok pada Kurikulum 2012

\begin{tabular}{|c|c|}
\hline $\begin{array}{c}\text { Matakuliah di Kurikulum } \\
2012\end{array}$ & $\begin{array}{c}\text { Matakuliah di Kurikulum } \\
2006\end{array}$ \\
\hline $\begin{array}{l}\text { Klasifikasidan Kodefikasi } \\
\text { Penyakit dan Masalah Terkait } \\
\text { I A }\end{array}$ & Biomedik Anatomi I \\
\hline $\begin{array}{l}\text { Klasifikasi dan Kodefikasi } \\
\text { Penyakit dan Masalah Terkait } \\
\text { I B }\end{array}$ & Biomedik Anatomi II \\
\hline $\begin{array}{l}\text { Praktek Klasifikasi dan } \\
\text { Kodefikasi Penyakit dan } \\
\text { Masalah Terkait I }\end{array}$ & Biomedik Fisiologi \\
\hline $\begin{array}{l}\text { Klasifikasi dan Kodefikasi } \\
\text { Penyakit dan Masalah Terkait } \\
\text { II A }\end{array}$ & Biomedik Patologi \\
\hline $\begin{array}{l}\text { Klasifikasi dan Kodefikasi } \\
\text { Penyakit dan Masalah Terkait } \\
\text { II B }\end{array}$ & Ilmu Peny. \& Lab Kes I \\
\hline $\begin{array}{l}\text { Praktek Klasifikasi dan } \\
\text { Kodefikasi Penyakit dan } \\
\text { Masalah Terkait II }\end{array}$ & Prakt. Ilmu Peny. \& Lab Kes I \\
\hline $\begin{array}{l}\text { Klasifikasi dan Kodefikasi } \\
\text { Penyakit dan Masalah Terkait } \\
\text { III }\end{array}$ & Ilmu Peny. \& Lab Kes II \\
\hline $\begin{array}{l}\text { Praktek Klasifikasi dan } \\
\text { Kodefikasi Penyakit dan } \\
\text { Masalah Terkait III }\end{array}$ & $\begin{array}{l}\text { Praktek Ilmu Peny. \& Lab } \\
\text { Kes II }\end{array}$ \\
\hline $\begin{array}{l}\text { Klasifikasi dan Kodefikasi } \\
\text { Penyakit dan Masalah Terkait } \\
\text { IV }\end{array}$ & Ilmu Peny. \& Lab Kes III \\
\hline
\end{tabular}




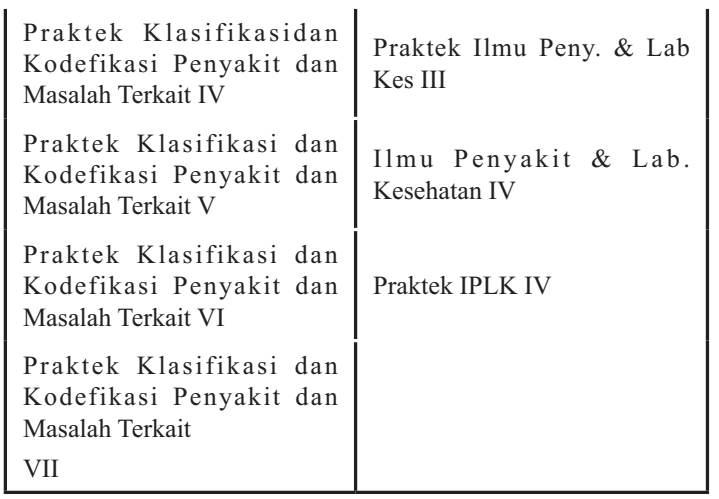

Sedangkan faktor yang menghambat dan strategi yang dilaksanakan pada implementasi kurikulum pada Program Diploma III Rekam Medis Sekolah Vokasi UGM adalah sebagai berikut:

Pada kurikulum peralihan yang diterapkan bagi mahasiswa angkatan 2011 dan sebelumnya, berdasarkan wawancara sebagian besar mahasiswa merasa dirugikan dikarenakan pada saat sesi entri data Kartu Rencana Studi (KRS) banyak mahasiswa yang kelebihan sisa sks. Strategi yang dilakukan oleh Program Studi adalah memberikan kesempatan pada mahasiswa waktu untuk memperbaiki KRS dan memberikan kesempatan bagi mahasiswa untuk menyampaikan keluhan melalui buku keluhan yang disediakan di bagian akademik.

Mahasiswa pada kurikulum peralihan merasa kebingungan ketika akan mengulang matakuliah pada kurikulum lama yang ternyata matakuliah tersebut sudah dihapus atau diganti nama matakuliah pada kurikulum baru. Baik mata kuliah tersebut mempunyai kesetaraan sebagian atau kesetaraan blok. Strategi yang diterapkan adalah mahasiswa tetap mengambil matakuliah berdasarkan kurikulum lama dan perkuliahan dititipkan pada matakuliah di kurikulum baru yang paling dekat kesetaraannya.

Dosen pengajar selama 3 semester berturutturut mengajar matakuliah yang sama, hal ini menyebabkan kebingungan pada dosen terkait. Hal tersebut merupakan strategi yang dilakukan dengan memberi kesempatan pada mahasiswa yang lama untuk memperbaiki nilai serta bagi mahasiswa baru dapat mengurangi sisa sks.

Dosen pengajar merasa dititipi mahasiswa yang mengulang matakuliah dengan kesetaraan sebagian atau kesetaran blok. Padahal dari segi materi sudah berbeda. Hal ini dilakukan dengan prinsip mahasiswa tidak dirugikan karena adanya perubahan kurikulum.
Sistem penyampaian materi matakuliah blok belum dilaksanakan di Program Diploma III Rekam Medis Sekolah Vokasi UGM seperti yang tercantum dalam Kurikulum Inti. Hal ini dikarenakan terbatasnya dosen matakuliah terkait serta silabus dan rencana program pembelajaran yang belum tersedia. Strategi yang dilakukan adalah dengan tetap menjalankan kurikulum baru tetapi disampaikan dengan metode keilmuan.

Masih terbatasnya silabus dan satuan ajaran perkuliahan berdasarkan kurikulum baru. Strategi yang dilakukan adalah melakukan pembuatan silabus dan rencana pembelajaran serta bekerjasama dengan Aptirmik terkait pembuatan serta sosialisasi silabus.

Berdasarkan penelitian Hadi (2012) dinyatakan bahwa Perencanaan materi pembelajaran merupakan persiapan-persiapan yang dilakukan oleh tenaga pendidik sebelum melaksanakan proses belajar mengajar. Perencanaan materi pembelajaran ini meliputi: peran serta tenaga pendidik dalam penyusunan silabus, keterkaitan standar kompetensi pada silabus dengan standar kompetensi lulusan, peran serta tenaga pendidik dalam penyusunan rencana pelaksanaan pembelajaran (RPP) dan peran serta tenaga pendidik dalam pembuatan modul. Hal tersebut akan terlaksana jika ada dukungan dari pihak internal program studi. Dalam hal ini Program Diploma III Rekam Medis Sekolah Vokasi UGM mendukung pelaksanaan implementasi kukrikulum mulai dari tahapan implementasi serta penyiapan dokumen pembelajaran yang meliputi pembuatan silabus, RPP, sampai dengan modul pembelajaran. Hal ini sesuai dengan Nurdin \& Usman (2003) yang menyatakan bahwa betapapun bagusnya suatu kurikulum, hasilnya akan tergantung pada kesiapan guru dan peserta didik. Sedangkan menurut Mulyasa (2007) dna Firmansyah (2007) menyatakan bahwa faktor terpenting dalam pengembangan kurikulum adalah otonomi dari instansi pendidikan serta menyesuaiakn dengan karakteristik dari keilmuwan, kemampuan dari instansi dan karakteristik dari peserta didik. Selain itu dalam pengembangan kurikulum harus mengacu pada kerangka dasar kurikulum dan standar kompetensi lulusan.

Mengingat potensi kendala yang dihadapi dalam penerapan kurikulum, ada beberapa saran untuk mengatasi berbagai kendala tersebut, yaitu (Firmansyah, 2007): Pertama, penyediaan model kurikulum yang lengkap dan "benar". Penyediaan 
Dedy, dkk. The Role og Health Information Management

ini merupakan suatu kebutuhan yang paling utama agar penyelenggaraan kurikulum tingkat satuan pendidikan dapat berjalandengan lancar; Kedua, sosialisasi yang efektif. Biasanya setiap kaliterjadi pergantian kurikulum, masalah yang sering dihadapi adalah kurang efektifnya sosialisasi yang dapat menimbulkan kesenjangan antara instansi pendidikan satu dengan instansi pendidikan lainnya.

\section{SIMPULAN}

Demikian pemaparan dari studi kasus implementasi kurikulum inti pada Program Diploma III Rekam Medis Sekolah Vokasi UGM, yang mana dalam implementasi masih ditemui banyak kendala. Namun strategi telah diupayakan dalam mengatasi kendala yang ada. Dalam hal ini diperlukan kerjasama baik antara instansi pendidikan, dosen, mahasiswa, organisasi profesi dan pengguna baik yag terlibat secara langsung maupun tidak langsung dalam proses pembelajaran, akan tetapi kurikulum yang dikembangkan harus dapat membatu mahasiswa mencapai kompetensi yang telah ditetapkan.

\section{DAFTAR PUSTAKA}

Machfoedz, I., Suryani, E., Sutrisno, Santosa, S. (2005) Pendidikan Kesehatan Bagian Dari Promosi Kesehatan. Ed. 2. Yogyakarta: Fitramaya.

Glanz, K., Lewis, F.M., Rimer, B.K. (1996) Health Behavior and Health Education: theory, research, and practice. 2nd ed. San Fransisco: Jossey-Bass Publisher.

Pribadi, B.A. (2009) Model Desain Sistem Pembelajaran. Jakarta: Dian Rakyat

Nurdin, S., \& Usman, M. B. (2003). Guru profesional \& implementasi kurikulum. Ciputat Pers.
Hadi, S. 2012. Jurnal Pendidikan Vokasi, Vol 2, Nomor 2, Juni 2012. Program Pascsarjana Universitas Negeri Yogyakarta

Mulyasa. 2007. Kurikulum Tingkat Satuan Pendidikan.Bandung: Remaja Rosdakarya.

Firmansyah, F. 2007. Implementasi Kurikulum Tingkat Satuan Pendidikan (Struktur dan Kendalanya). Tadris Jurnal Pendidikan Islam Vol. 2 No. 1. Pamekasan: Sekolah Tinggi Agama Islam.

UU No 12 tahun 2012 tentang Pendidikan Tinggi

Peraturan Pemerintah No.17 Tahun 2010 tentang Pengelolaan dan Penyelenggaraan Pendidikan

Kepmendiknas No. 232 tahun 2000 tentang Pedoman Penyusunan Kurikulum Pendidikan Tinggi dan Penilaian Hasil Belajar Mahasiswa

Kepmendiknas No. 045 tahun 2002 tentang Kurikulum Inti Perguruan Tinggi

Kepmenkes No 377 Tahun 2007 tentang Standar Profesi Rekam Medis dan Informasi Kesehatan

Keputusan Kepala Badan Pengembangan dan Pemberdayaan Sumber Daya Manusia Kesehatan Nomor: HK.02.05/ I/ III/ 2/ 08661/ 2011 Tentang Kurikulum Inti Program Pendidikan Diploma III Rekam Medis dan Informasi Kesehatan

Machfoadz, I, sSuryanie, Sutrisno, Santosa, S. 2005. Pendidikan Kesehatan Bagian Dari Promosi. 